\title{
Utilization of Household Organic Waster (Leachate Water) as a Source of Liquid Organic Fertilizer with the Addition of Bio activators (Case Study: Congko Village, Marioriwawo District, Soppeng Regency)
}

\author{
Munawwarah Nawir'1, Muchtar Salam Solle², Kahar Mustari ${ }^{3}$ \\ ${ }^{1}$ Environmental Management Study Program of Graduate School, Hasanuddin University, 90245, Makassar, Indonesia. \\ ${ }^{2}$ Department of Soil Science, Faculty of Agriculture, Hasanuddin University, 90245, Makassar, Indonesia. \\ ${ }^{3}$ Department of Agricultural Cultivation, Faculty of Agriculture, Hasanuddin University, 90245, Makassar, Indonesia.
}

Correspondence Author: Kahar Mustari, Department of Agricultural Cultivation, Faculty of Agriculture, Hasanuddin University.

Email: kahar_mustari@yahoo.com

Received date: 20 December 2019, Accepted date: 28 January 2020, Online date: 22 February 2020

Copyright: (C) 2020 Munawwarah Nawir et al. This is an open-access article distributed under the terms of the Creative Commons Attribution License, which permits unrestricted use, distribution, and reproduction in any medium, provided the original author and source are credited.

\begin{abstract}
They are overcoming the problem of waste by changing or utilizing it as raw material for liquid organic fertilizer for the production of natural materials. Manage biological household-scale wastewater (leachate water) originating from households with an anaerobic process (without oxygen). This study aims to analyze the effect of leachate water with the addition of bio activators and analyze the content of liquid organic fertilizer based on quality standards according to the criteria of the Minister of Agriculture Regulation 2011. This research was conducted in September 2019 to December 2019, located in Congko Village, Marioriwawo District, Soppeng Regency. Testing liquid organic fertilizer; Makassar Laboratory Center, This type of research, is an experimental study that aims to determine the effect of adding bio activator types, variations in wastewater (rice washing water and old coconut water). Chemical observations ( $\mathrm{pH}, \mathrm{C}$ Organic, C / N ratio, Nitrogen, $\mathrm{Fe}, \mathrm{Mn}, \mathrm{Cu}, \mathrm{Zn}$, E. coli). The results showed that the entire sample of a combination of liquid organic fertilizer produced using MOL activator (pineapple and cow urine with variations of wastewater (rice washing water and old coconut water) gave a more productive work in degrading garbage. The combination of liquid organic fertilizer from the sample tested B2A2 (MOL bio activator (cow urine) + old coconut water)) almost meets the standard but, the micronutrient element that is $\mathrm{Cu}$ has not approached the minimum quality standard according to the criteria of the Minister of Agriculture Regulation 2011.
\end{abstract}

Keywords: Waste waste, liquid organic fertilizer, Bio activator, rice water, old coconut water

\section{INTRODUCTION}

Increased population, rapid urbanization, improved economy, and rising living standards in developing countries greatly accelerate the level, amount, and quality of waste generation (global issues) attention in the world [1]. Development developments affect waste generation with a variety of forms, types, and composition into environmental problems that can be polluted [2]. Based on waste management, Law No. 18 of 2008, regarding waste management that waste is the remnant of daily human activities or natural processes in the form of solid waste. Moreover, if it is not managed correctly, it will hurt health and soil, water, and air, which impacts on social health problems [3]. There is a need for handling systems from the collection, management, to final disposal, considered to be one of the most challenging issues faced, especially in urban and rural areas (Abdel \& Mansour, 2018) [1].

Waste is found in several categories, namely: animal-based organic waste (manure), compost (plant sources) and urban waste (sewage sludge and household waste) from kitchen waste such as food scraps, flour, vegetables, fruit skins, wilted leaves. (Wayne et al., 2019) [4]. Overcoming problems at the source of waste (households) will be more effective because it is easier (small scale) and cheaper (affordable cost) by using a composter (Utami, 2018) [5]. This method can be used to manage organic household waste originating from households and home yards by utilizing leachate water Chiang et al. (2016) [6]. The formation of leachate from the decomposition of waste due to microbial activity that turns it into a more straightforward organic form. Initially, the waste is decomposed aerobically or anaerobically. The anaerobic process (does not require oxygen) requires the 
help of microbes contained in the bio activator in the presence of carbohydrates that are self-produced, namely MOL (Local Micro-Organisms) from substantial laundry wastewater and coconut water.

According to Wenda (2017) states through the use of liquid organic fertilizer from organic waste that is environmentally friendly, it is expected to replace the role of expensive chemical fertilizers commonly used by the public so far [7]. With conservation to help reduce the impact of waste-producing the effect of minimizing environmental damage, integrated nutrient management strategies from liquid organic fertilizers were developed to increase the sustainability of crop production and dynamic growth [7].

\section{MATERIALS AND METHODS}

This research will be carried out in different locations, namely taking organic waste and making liquid organic fertilizer and observing plants in the Congko Village, Marioriwawo District, Soppeng Regency. The study began in September to December 2019.

The tools used in this study consisted of tools used in the composting process, namely used paint containers ( 25 liters), bottles, machetes, wooden spoons, measuring cups, $\mathrm{pH}$ meters, thermometers, analytical balance, and writing and laptop stationery. The materials used in this study are organic waste from household waste (food scraps, vegetable scraps, and fruit skins, bio activators (ready to use) in the form of bio activators (cow urine), groundwater, brown sugar water, coconut water, pineapple as a manufacture bio activator (Pineapple Local Microorganism).

The preparation stage for making liquid organic fertilizer from household rumors is taking household scale (leftover vegetables, leftover food, fruit skin), i.e., at the author's house and added nine apartments closest to the author's home by providing a trash can or While the population is the mass community house in Congko Village, Marioriwawo District, Soppeng Regency.

The making phase of MOL bio activator (Pineapple Local Microorganism), rice washing water mixed with brown sugar is put in a bottle and stirred until well blended. Pineapple that has been mashed up is inserted, stirring again until evenly mixed, the bottle is closed with a lid and fermented for 15 days (see ap days open the bottle cap until the smell of the tape caused by fermentation). It is making liquid organic fertilizer by cutting vegetables, food scraps, and fruit skins. Massive organic waste will be chopped/chopped with a size of $\pm 2 \mathrm{~cm}$ in advance, aiming to refine the surface of the trash so that it is easily and quickly decomposed into liquid organic fertilizer. It is dissolving (utilizing coconut wastewater and rice washing water) by mixing organic material until evenly distributed, save for \pm 30 days. The next process is spraying a MOL bio activator solution (pineapple and cow urine) that has been made, strived evenly to the entire surface of the garbage in the composter unit every seven days.

\section{Map Of Congko Village, Marioriwawo District, Soppeng Regency, South Sulawesi}

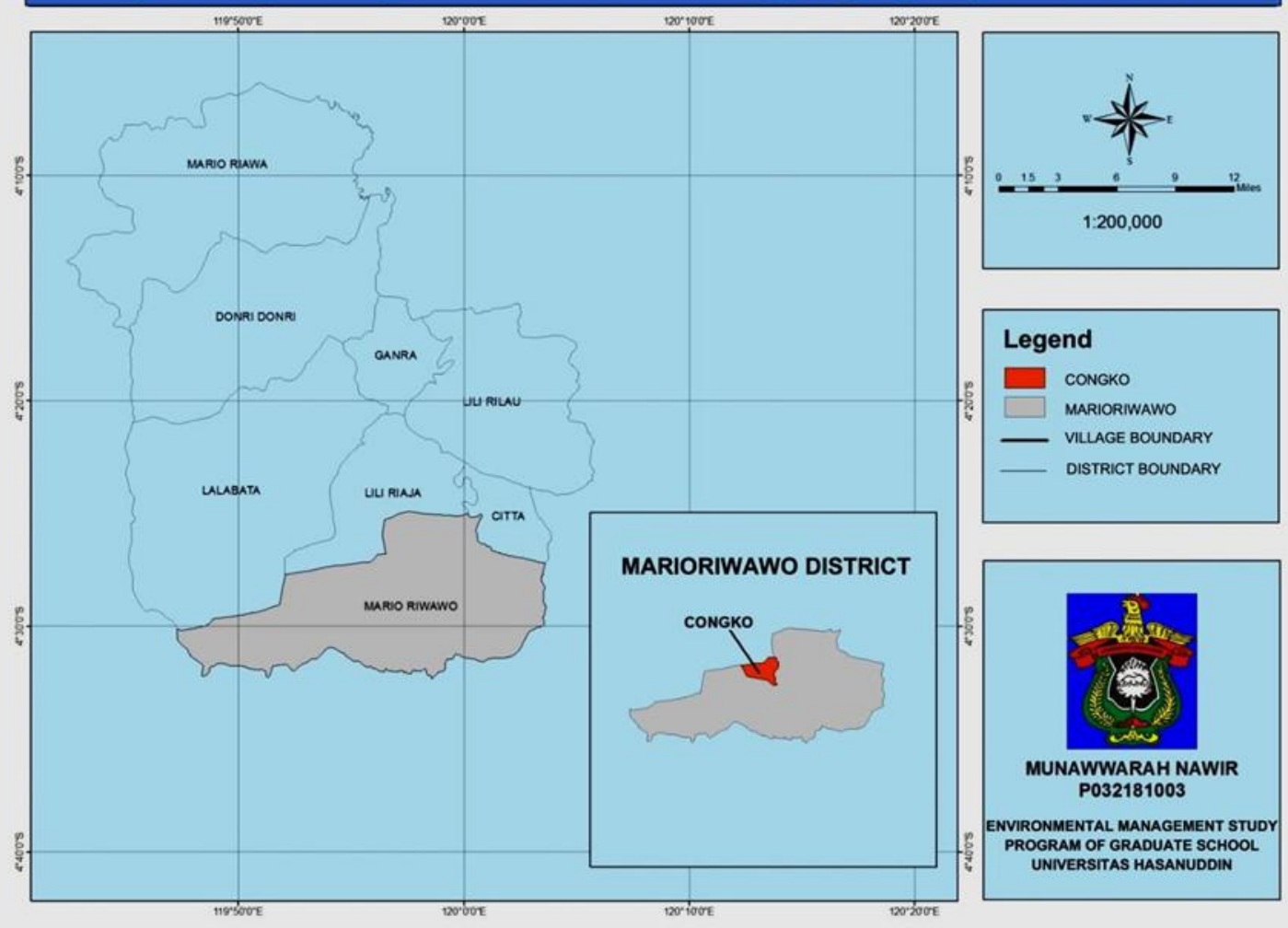

Fig. 1: Research location of Congko Village Kec. Marioriwawo Kab. Soppeng, South Sulawesi 


\section{RESULTS}

\section{The Effect of Composting Liquid Organic Fertilizers with the Addition of Bio activators (Local Microorganisms)}

Making anaerobic organic fertilizer (fermentation) is done to help decomposition. The composter container used has two spaces above the substantial waste bins and under the presence of liquid from the waste. Considerations for making composter in terms of cost and level of complexity are considered more suitable to the culture of the local community because it is more easily applied and low manufacturing costs.
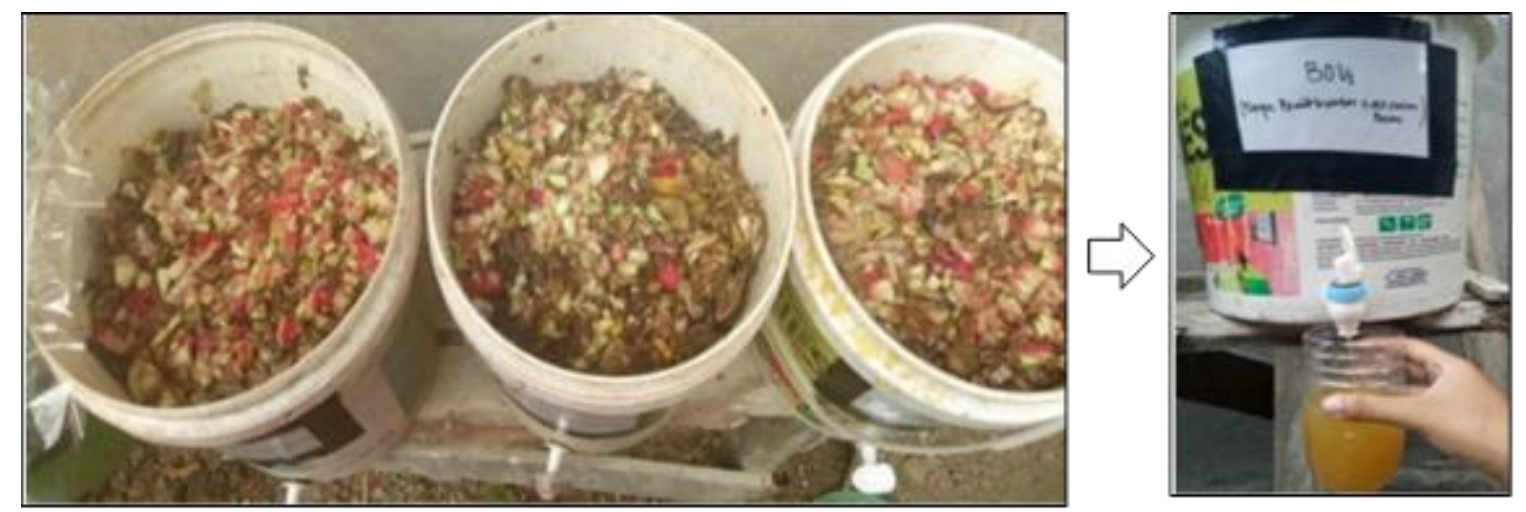

Fig. 2: Composter containers (utilizing used paint) (Personal Documentation, 2019).

Household organic waste has been was collected (Fig. 2). The process of fermentation is by varying the composition of liquid organic fertilizer in mixing of rice washing water and old coconut water with organic waste, and the addition of bio activators (without bio activators, pineapple MOL and cow urine). The use of bio activators can accelerate the composting process until the 28th day so that the proliferation of microorganisms that are activated during the process of making liquid organic fertilizer. The results of the fermentation are then ready to be applied. In general, they have different characteristics in the composting process, both physically, chemically and biologically. During the experimental process, an observation was made of the dynamics in the composter unit. The representations are depicted in Table 1.

Table 1: Observation results of the process of making liquid organic fertilizer

\begin{tabular}{|c|c|c|c|c|}
\hline No. & Week & Color & Odor & Remarks \\
\hline \\
\hline 2. & First Day 7 & Yellow & $\begin{array}{l}\text { Smelling of rotten cabbage } \\
\text { and kale }\end{array}$ & $\begin{array}{c}-\quad \text { Maggot or flies no } \\
-\quad \text { BrownishRough, moist and high moisture content } \\
\text { entering } \\
-\quad \text { Shrinking } 8 \mathrm{~cm}\end{array}$ \\
\hline \multicolumn{5}{|c|}{$\begin{array}{l}\text { 3. * coconut water and rice washing water then adding bio-activator MOL (previously made pineapple and urine ..cow } \\
\text { each composter. }\end{array}$} \\
\hline 4. & Second Day.14 & $\begin{array}{c}\text { Dark } \\
\text { brown }\end{array}$ & Stinging stench No & $\begin{array}{cc}- & \text { Maggots or flies } \\
- & \text { Rough, soft, crumbling, high moisture content } \\
- & \text { Shrink } 10 \mathrm{~cm} \\
\end{array}$ \\
\hline \multicolumn{5}{|c|}{$\begin{array}{l}\text { 5. * Add organic waste (shrink) and add coconut water and rice washing water and then add MOL bio activators } \\
\text { (pineapple fruit) and cow urine) ..each composter. }\end{array}$} \\
\hline 6. & Third-Day.21 & $\begin{array}{c}\text { Dark } \\
\text { brown }\end{array}$ & Stinging stench No & $\begin{array}{cc}- & \text { Maggots or flies } \\
- & \text { BrownishRough has a high moisture content } \\
- & \text { Shrinks to } 10 \mathrm{~cm} \\
\end{array}$ \\
\hline \multicolumn{5}{|c|}{$\begin{array}{l}\text { 7. *Add organic waste (shrink) to full and include coconut water and rice washing water and then the addition of MOL bio } \\
\text { activators (fruit ..pineapple and cow urine) each composter. }\end{array}$} \\
\hline 8. & $\begin{array}{l}\text { The fourth } \\
\text { day.28 }\end{array}$ & Brown & Rotten odor does not sting No & $\begin{array}{c}-\quad \text { Maggots or flies } \\
\quad \text { Concentrated, soft and still contains water content }\end{array}$ \\
\hline \multicolumn{5}{|c|}{ 9. *Day 30 harvesting liquid organic fertilizer is put into a bottle. } \\
\hline
\end{tabular}

Note: * the addition of organic waste when organic waste shrinks.

Based on Table 1. it shows that the process of making liquid compost is first by putting the garbage in a composter container, then spraying it with rice and coconut water wash water, then add $250 \mathrm{ml}$ of MOL (pineapple and cow urine) solution. Spraying 
MOL solution (pineapple and cow urine). After spraying with MOl solution (pineapple and cow urine), the composter unit is covered with a cover (which is covered with plastic wrap using a rubber band on the outside).

Observations on the following day, day 14 and day 21 showed conditions that were relatively the same as the previous observer. The texture of the rubbish is still rough, and some become small seraph. The colour of the garbage turns dark brown, the stench is relatively mild, and the volume of waste undergoes a reduction (volume shrinkage) of about $10 \mathrm{~cm}$. Then the observation after the 28th day (4 days), the production of liquid compost was quite large, and the compost was relatively odourless. Still, the conditions in each composter were not infested by flies or grubs. The next process is the 30th day harvesting liquid organic fertilizer by entering into a $600 \mathrm{ml}$ bottle and then adding back MOL (pineapple and cow urine) to ferment for 10-15 days so that it is dark brown.

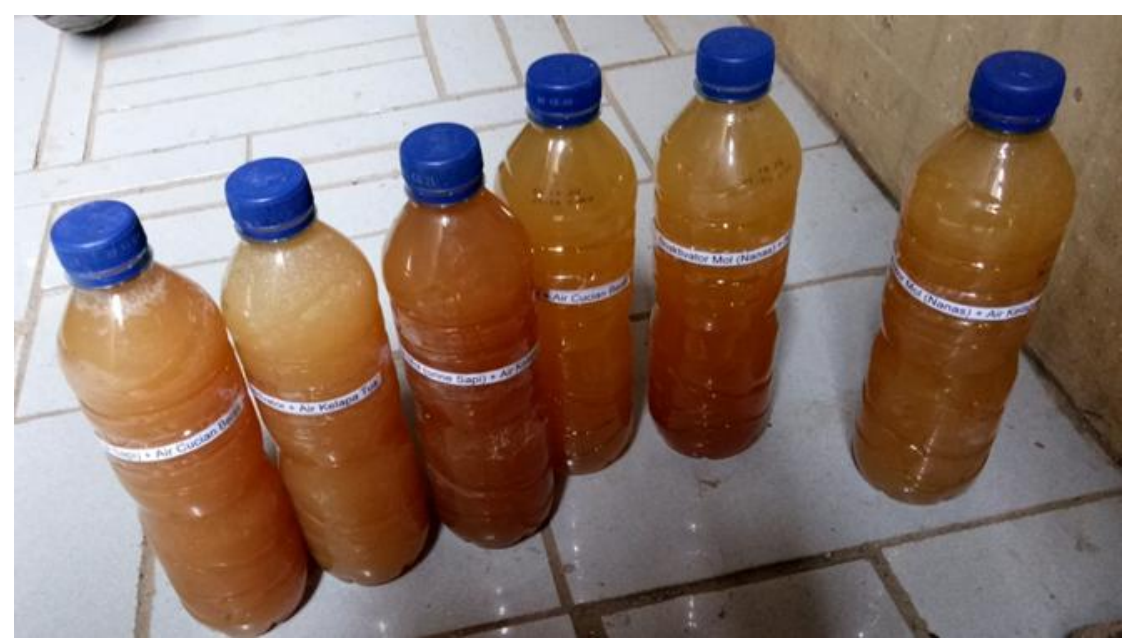

Fig. 3: Fermentation results in liquid organic fertilizer

\section{Content Analysis of Liquid Organic Fertilizer}

Analysis of Macro and Micro Nutrients in the Laboratory of liquid organic fertilizer

Table 2: Comparison of Laboratory Test Results From Liquid Organic Fertilizer With Quality Standard by the Minister of Agriculture in 2011.

\begin{tabular}{|c|c|c|c|c|c|c|c|c|}
\hline \multirow{2}{*}{ Parameter } & \multirow{2}{*}{ Unit } & \multirow{2}{*}{ 2011 Quality Standard Permenta } & \multicolumn{5}{|c|}{ Combination Samples } \\
\cline { 5 - 9 } & & & B0A1 & B1A1 & B2A1 & B0A2 & B1A2 & B2A2 \\
\hline pH & & $4-9$ & $6.4^{\mathrm{a}}$ & $7^{\mathrm{a}}$ & $7^{\mathrm{a}}$ & $6.4^{\mathrm{a}}$ & $7^{\mathrm{a}}$ & $7^{\mathrm{a}}$ \\
\hline C- Organic & $\%$ & Min 6 & $13.44^{\mathrm{a}}$ & $40.16^{\mathrm{a}}$ & $33.03^{\mathrm{a}}$ & $68.40^{\mathrm{a}}$ & $60.57^{\mathrm{a}}$ & $92.36^{\mathrm{a}}$ \\
\hline C / N Ratio & & $15-25$ & $9.08^{\mathrm{b}}$ & $9.12^{\mathrm{b}}$ & $13^{\mathrm{b}}$ & $9.85^{\mathrm{b}}$ & $9.10^{\mathrm{b}}$ & $15.08^{\mathrm{a}}$ \\
\hline Nitrogen & $\%$ & Min 6 & $42.91^{\mathrm{a}}$ & $37.9^{\mathrm{a}}$ & $54.0^{\mathrm{a}}$ & $53.8^{\mathrm{a}}$ & $50.6^{\mathrm{a}}$ & $71.6^{\mathrm{a}}$ \\
\hline Fe & $\mathrm{ppm}$ & $5-50$ & $2.11^{\mathrm{b}}$ & $5.09^{\mathrm{a}}$ & $5.58^{\mathrm{a}}$ & $4.05^{\mathrm{b}}$ & $5: 58^{\mathrm{a}}$ & $11.17^{\mathrm{a}}$ \\
\hline Mn & $\mathrm{ppm}$ & $250-5000$ & $0.05^{\mathrm{b}}$ & $0: 06^{\mathrm{b}}$ & $100.10^{\mathrm{a}}$ & $0.20^{\mathrm{b}}$ & $104.14^{\mathrm{a}}$ & $25013^{\mathrm{a}}$ \\
\hline Cu & $\mathrm{ppm}$ & $250-5000$ & $<0.01^{\mathrm{b}}$ & $<0.01^{\mathrm{b}}$ & $0.01^{\mathrm{b}}$ & $<0.01^{\mathrm{b}}$ & $<0.01^{\mathrm{b}}$ & $0.01^{\mathrm{b}}$ \\
\hline Zn & $\mathrm{ppm}$ & $250-5000$ & $5.68^{\mathrm{b}}$ & $17.98^{\mathrm{b}}$ & $166.62^{\mathrm{b}}$ & $36.34^{\mathrm{b}}$ & $136.61^{\mathrm{b}}$ & $256.05^{\mathrm{a}}$ \\
\hline E.coli & MPN/ml & Max $10^{2}$ & 0 & 0 & 0 & 0 & 0 & 0 \\
\hline
\end{tabular}

Description:

1. Symbol a: Issuer (top-quality standard quality standards according to the 2011 Pementa)

b: below (below the quality standard according to the 2011 Pementa Quality)

2. Sample Code $=$ B0A1: Organic waste + without-bio activator + rice water; B1A1: Organic waste + Bioactivator $($ pineapple fruit MOL) + rice water; B2A1: Vegetable and fruit peels + Bioactivator (cow urine MOL) + rice water; B0A2: Organic waste + Without Bioactivator + old coconut water; B1A2: Organic waste + Bioactivator (pineapple fruit MOL) + old coconut water; B2A2: organic waste + Bioactivator (MOL of cow urine) + old coconut water. The results of experiments with B2A2 (organic waste + bio-activator MOL (cow urine) + old Kepa water) are almost close to the minimum based on quality standards. Based on the Minister of Agriculture Regulation No. 70 of 2011, micronutrients such as Mn, Fe, Zn have values above the minimum standard quality. Still, the $\mathrm{Cu}$ has 0.01 contained in liquid organic fertilizer far below the standard of less than 250-5000. Neither the other samples have values below the standard $<0.01$. The $\mathrm{pH}$ and macronutrients, including the N, C-Organic, C / N Ratio, meet the quality standards and do not contain e-coli microbes. Of the nine parameters based on the Regulation of the Minister of Agriculture No. 70 of 2011, the combination of the composting results that have been examined is not yet suitable to be used as liquid organic fertilizer (Kementan, 2011). 
Fermentation takes 10-15 days after harvesting liquid organic fertilizer with the anaerobic composting process. The results of experiments with B2A2 (organic waste + MOL bio activator (cow urine) + old coconut water) are almost close to the minimum based on quality standards.

Based on the Regulation of the Minister of Agriculture No. 70 of 2011, micronutrients such as Mn, Fe, Zn have values above the minimum standard quality standard. Still, $\mathrm{Cu}$ has 0.01 contained in liquid organic fertilizer far below the standard of less than 250-5000. Neither the other samples have values below the standard $<0.01$. The $\mathrm{pH}$ and macronutrients, namely $\mathrm{N}$, C-Organic, C / N Ratio, meet the quality standards and do not contain microbial types of e.coli. Of the nine parameters based on the Regulation of the Minister of Agriculture No. 70 of 2011, the combination of the composting results that have been examined is not yet suitable to be used as liquid organic fertilizer (Kementan, 2011).

\section{DISCUSSION}

\section{Effect of Liquid Organic Fertilizer With Addition of Bio activators}

Based on According to Bharti et al. 2016, another form of utilization, one of which is used as compost or liquid organic fertilizer to use kitchen scraps found in daily activities [2]. Research conducted by Erickson, 2013 states that a good dose of MOL used as a bio activator for making liquid compost is a dose of $250 \mathrm{ml}$ [8]. The use of moles is quite a lot, and the composting time is very influential on the quality of the moist fertilizer produced [3]. This depends on the composition and characteristics of the composting material. The symptoms of waste are also determined by the specificity of garbage from several places and different types that allow different properties (Nasir, 2015) [9].

In the composting process, there was also a significant decrease in water content and a reduction in volume in the MOL treatment. Compost maturity can also be seen from the weight loss of compost by 60-70\% (Hati, 2018) [10]. This is due to the decomposition of microorganisms getting better with increasing until reach equilibrium, i.e., the number of microbes produced is equal to the number of dead bacteria so that at this time, microbial activity will decrease due to the decrease in volume and biomass of the material. So that it affects the concentrated liquid organic fertilizer will be produced (Hesti, 2015) [11].Organic waste from microorganisms that turn into nutrients, $\mathrm{CO} 2, \mathrm{H} 2 \mathrm{O}$, and energy (484-674 $\mathrm{kcal} / \mathrm{mol}$ glucose). In the process of making compost, it is caused by anaerobic composting, which is the process of decomposition of organic material without using $\mathrm{O} 2$, so that the composting media uses plastic (used paint containers) whose edges are covered with vinyl for a specified time (Wang et al., 2019) [12].

\section{Effect of Content Analysis From Liquid Organic Fertilizer}

This spurred by the quality standard requirements. Benchmark on ministerial regulation No 70 / Permentan / SR.140 / 10/2011 regarding standard standards for liquid organic fertilizer, the type of organic waste sample produces water as a type of liquid organic fertilizer [13]. Further research is needed on the manufacture of liquid organic fertilizer to produce liquid organic fertilizer that genuinely meets the quality standard. Observation of macro and micronutrients, pH, C-organic, Nitrogen, $\mathrm{C} / \mathrm{N}$ ratio, $\mathrm{Fe}, \mathrm{Mn}, \mathrm{Cu}, \mathrm{Zn}$ and e-coli microbes.

Measurement of chemical parameters in the laboratory of $\mathrm{pH}, \mathrm{C}$-organic, Nitrogen, $\mathrm{C} / \mathrm{N}$ ratio, $\mathrm{Fe}, \mathrm{Mn}, \mathrm{Cu}, \mathrm{Zn}$ and microbial e.coli concerning standards meeting SNI requirements according to the 2011 Minister of Agriculture Regulation as liquid organic fertilizer, although there are several parameters lower, so it needs to get a more in-depth discussion.

a. $\mathrm{pH}$

$\mathrm{pH}$ measurements on each combination of the six samples have met the quality standard requirements of 4-9 showing the difference at the beginning and end of fermentation. Alkaline $\mathrm{pH}$ causes nitrogen content to rise or fall; it can be concluded that the increase in nitrogen content is caused by the pH produced by acid (Roubik, 2018) [14].

\section{b. C-Organic}

The content of compost C-organic which is in the high range, exceeds the limits of SNI Permentan 2011, which is min 6. The data gives an illustration of the existence of compost products that have high C-organic content (Wulandari at al, 2015) [15].

\section{c. C / N Ratio}

Composting causes an increase in nitrogen content $(\mathrm{N})$ so that the compost $\mathrm{C} / \mathrm{N}$ ratio decreases, indicating the value below the fifth standard of liquid organic fertilizer combinations, namely B0V1, B1V1, B2V1, B0V2, B1B2 does not meet the requirements. Well, the combination of $\mathrm{B} 2 \mathrm{~V} 2$ shows the value above the standard according to the regulation of the minister of agriculture in 2011. The high nitrogen content of local microorganisms with the addition of bananas based on test results because bananas contain protein. Fermentative organisms can overhaul the protein into nutrients (Elouear et al., 2016) [16]. This was confirmed by the research of Ramaditya et al. (2017) [17] that an increase in the element nitrogen as a product of protein breakdown from the decomposition process.

d. Nitrogen

The six liquid organic fertilizer combination samples can be said to exceed the requirements. This is due to the overhaul of organic material by nitrites bacteria turning ammonia into the final nitrate composting (Ginting, 2017) [18].

e. Microelements (Fe, $\mathrm{Mn} \mathrm{Cu}$, and $\mathrm{Zn}$ ) and e.coli

Microelements in combination with B2V2 samples (organic waste + bio-activator MOL (cow urine) + old coconut water) fulfill the microelement content (Fe, Mn and $\mathrm{Zn}$ ) of compost studied in general meet the 2011 Permentan standard, except for $\mathrm{Cu}$ from 
the six combinations the sample. It needs to be investigated further whether there is an error in the analysis, or there is a connection to the fifth sample combination. According to Nurhasanah (2013) [19], Micro Essential Micro (Fe, Mn Cu, and Zn) in liquid organic fertilizer has the opportunity to function as a source of nutrients for plants. In the composting process, microorganisms usually grow and breed. Still, the formation of toxic free radicals due to high C-organic in the anaerobic process resulting in the growth of pathogenic bacteria, namely e.coli, cannot live without air (Saputri, 2018) [20].

\section{CONCLUSIONS}

Based on research conducted by Congko Village, Marioriwawo District, Soppeng Regency, there was a change in organic waste affecting the MOL bio activator solution (pineapple and cow urine) with rice washing water and coconut water and every day experiencing changes in colour, smell, texture to shrinkage. The sixth quality combination of liquid organic fertilizer from physical Observation (colour, odour, $\mathrm{pH}$ temperature, humidity) shows the mature phase and chemical observation (pH, $\mathrm{C}$ Organic, $\mathrm{C} / \mathrm{N}$ ratio, Nitrogen, $\mathrm{Fe}, \mathrm{Mn}, \mathrm{Cu}, \mathrm{Zn}$, E.coli ) produced free from microbial contaminants (pathogens). $\mathrm{Cu}$ micronutrient parameters are below the standard close to the minimum based on the Regulation of the Minister of Agriculture No. 70 of 2011 .

\section{ACKNOWLEDGEMENT}

Authors thank Nurul Anuqrah, Riska Febriani, Kurniaty, Ahmad Nurdyanto and my friends in Environmental Management at the graduate school of Hasanuddin University Makassar outstanding support in field and laboratory works.

\section{REFERENCES}

[1] Abdel, S. H. I \& Mansour, M.S.M, 2018. Substantial waste issues: sources, composition, disposal, recycling, and valorization.Egyptian Journal of Petroleum, 4(8):1-5.

[2] Bharti PK, Sharma B, Singh RK, Tyagi AK. 2016. Waste generation and management in Antarctica.Procedia Environmental Sciences, 35: 40-50.

[3] Law of the Republic of Indonesia No. 18 of 2008 concerning waste management. [in Indonesia]

[4] Wayne, K. C, Shir R. C, Hong W. Y, Saifuddin N, Yeek C. H and Pau L. S, 2019. Transformation of biomass waste into sustainable organic fertilizers.Sustainability journal, 2019, (11): 22-66.

[5] Utami, Ir, MS, 2018. Symptomatic symptoms of essential nutrients in several types of plants. Agroecotechnology study program. Udayana University. Denpasar. [in Indonesia]

[6] Chiang, PN, Tong, OY, Chiou, CS, Lin, YA, Wang, MK, Liu, CC, 2016. Reclamation of zinc-contaminated soil using a dissolved organic carbon solution prepared using liquid fertilizer from food - waste composting.J. Hazard. Mater, 301: $100-105$.

[7] Wenda, M., S, Hidayanti \& S, Purwanti, 2017. Application of liquid organic fertilizer and plant media composition against lettuce (lactuca sativa L.).Gontor Agrotech Science Journal, 3: 2.

[8] Erickson, S, 2013. Making liquid and biogas fertilizers from mixed vegetable waste.USU Chemical Engineering Journal, 2(3): 44.

[9] Nasir, M, 2015. Characteristics of traditional market solid waste composting with the natural static pile system. Master Thesis. Bogor Agricultural University. Bogor. [in Indonesia]

[10] Hati, S, 2018. Making liquid compost fertilizer from household waste as a support for ecology and environmental problems courses. Thesis: faculty of Tarbiyah and teacher training. Ar-Raniry State Islamic University. Darussalam Banda Aceh. [in Indonesia]

[11] Hesti, HS, 2015. Test the quality of liquid organic fertilizers from various types of local microorganisms (moles).El-Vivo Journal, 3:01.

[12] Wang, J., Sun, N., Xu, M., Wang, S., Zhang, J., Cai, Z., Cheng, Y, 2019. The influence of long-term animal manureand crop residue application on abiotic and biotic $\mathrm{N}$ immobilization in an acidified agricultural soil.Geoderma, 337: 710-717.

[13] Minister of Agriculture of the Republic of Indonesia, 2011. Regulation of the minister of agriculture No. 70 / Permentan / SR.140 / 10/2011. About organic fertilizers, biofertilizers and soil enhancers. State gazette of the republic of Indonesia. [in Indonesia]

[14] Roubik, H., Mazancova, J., Banout, J., 2018. The current approach to management for small-scale southeast Asian farmersusing Vietnamese biogas and non-biogas farms as an example.Renew. Energy, 115: 362-370.

[15] Wulandari, L., M. Junus., E. Setyowati., 2015. Effect of aeration and addition of silica with different ripening on the content of N, P, and K liquid fertilizer unit Biogas. Master Thesis. Faculty of Agriculture. Brawijaya University. [in Indonesia]

[16] Elouear, Z., Bouhamed, F., Boujelben, N., Bouzid, J, 2016. Application of sheep mae and potassium fertilizer to contaminated soil and its ect on zinc, cadmium and lead accumulation by alfalfa plants.J. Sust. Environ. Res, 26: 131135.

[17] Ginting. JK, 2017. Growth and production response of two lettuce varieties (lactuca sativa 1.) against the provision of various sources of nitrogen. Master Thesis. Agroecotechnologys Study program. Faculty of agriculture. The University of North. Sumatra.Field. [in Indonesia] 
[18] Ramaditya, I., Hardiono, Z., Ali A., 2017. The effect of addition of em-4 bioactivators (effective microorganisms) and moles (local microorganisms) stale rice against the time of compost.Journal of environmental health, 14: 1.

[19] Nurhasanah, 2013. Leachate processing and Its potential use as liquid fertilizer to support the development of sustainable solid waste landfill (case study of Galuga solid waste landfill in Bogor regency). Undergraduate Thesis. Bogor Agricultural Institute. Bogor. [in Indonesia]

[20] Saputri, LD, 2018. The effect of addition of leachate with mole and leachate without mole on the process of organic waste composting in TPA Winongo. Master Thesis. Bhakti Husad Mulia. Madiun. [in Indonesia] 